\title{
GEOMORFOLOGIA E ÁREAS DE EXPANSÃO URBANA DO MUNICÍPIO DE GARANHUNS-PE: UMA ABORDAGEM ESPAÇO-TEMPORAL DOS EVENTOS MORFODINÂMICOS PARA O PLANEJAMENTO TERRITORIAL
}

\author{
GEOMORPHOLOGY AND EXPANSION OF URBAN AREAS GARANHUNS-PE COUNTRY: A SPACE-TIME \\ APPROACH OF MORPHODYNAMIC EVENTS FOR TERRITORIAL PLANNING
}

\author{
Renata Nunes Azambuja \\ Universidade Federal de Sergipe (UFS), São Cristóvão, SE, Brasil, renatanaz@yahoo.com.br \\ Antonio Carlos de Barros Corrêa \\ Uiversidade Federal de Pernambuco (UFPE), Recife, PE, Brasil, dbiase2001@terra.com.br
}

\begin{abstract}
RESUMO
O fenômeno de expansão urbana sobre cidades de pequeno e médio porte no Brasil tem conferido aos diversos ambientes geomorfológicos mudanças notáveis em seu funcionamento e limites de ruptura, promovendo respostas rápidas, diretamente sobre a estabilidade da paisagem. Este trabalho se propõe a analisar sob uma perspectiva espaço-temporal, mudanças ocasionadas pelo uso da terra ao longo de mais de quatro décadas ocorridas no município de Garanhuns-PE. Com visitação reconhecimento e interpretação do significado da dinâmica processual atual, o mapeamento morfodinâmico em escala espaço-temporal ensejou reconhecer diversos processos superficiais relacionados à topografia, estrutura lito-pedológica e cobertura vegetal. A sedimentologia e mineralogia dos materiais analisados demonstrou que o processo de erosão e transporte, em curto prazo, tem favorecido um acúmulo de depósitos de textura grossa e inversão do relevo em setores de baixa encosta a partir da formação de novos knickpoints. Assim, foi possível estabelecer uma forte relação entre atividades antrópicas e o aumento da sensitividade da paisagem, sobretudo quando relacionada a modificações no sistema climático, operando em diversas escalas de tempo.
\end{abstract}

Palavras-chave: Mapeamento morfodinâmico; Propriedade dos solos; Ação antrópica, Planalto da Borborema; análise espaço-temporal.

\section{ABSTRACT}

The urban expansion phenomenon on small and medium-sized cities in Brazil has given in several geomorphological environments notable changes in their operation and break boundaries, promoting rapid responses, directly on the landscape stability. This work aims to analyze, on a spatial-temporal perspective, changes caused by land use over more than four decades occurred in Garanhuns-PE municipality. With visitation recognition and interpretation of the meaning of the current dynamic process, the morphodynamic mapping in scale space-time led to recognize several surface processes related to topography, litho-pedological structure and vegetation cover. The sedimentology and mineralogy of the analyzed material showed that the process of erosion and transport in the short term, has favored a buildup of deposits of coarse texture and inversion of relief in low slope areas from the formation of new knickpoints. Thus, it was possible to establish a strong relationship between human activities and the increase of landscape sensitivity, especially when related to changes in the climate system, operating in different time frames.

Keywords: Morphodynamic mapping; Soil property; Human action, Borborema Plateau; Space-time analyze.

Artigo recebido para publicação em junho de 2015

Artigo aceito para publicação em setembro de 2015

\section{INTRODUÇÃO}

A área urbana do município de Garanhuns, no decorrer das últimas décadas, tem apresentado uma crescente taxa de expansão dos seus limites, resultando, em uma primeira fase, na construção de vários 
conjuntos residenciais destinados às classes de baixa renda (as denominadas COHAB'S) e, em um segundo momento (mais recente), em áreas de interesse especulativo imobiliário, para construção de condomínios de classe média-alta. Este é um caso ilustrativo de ações deliberadas do planejamento público, bem como de ações privadas, sem prévio controle, que hoje são os maiores responsáveis pelo desencadeamento de processos-resposta sobre os sistemas físico-naturais, em nível local.

O reconhecimento em campo de paleofeições, típicas de retomadas erosivas sobre a paisagem de Garanhuns, demonstra que a área em questão já esteve sujeita a episódios de alta vulnerabilidade aos agentes morfogenéticos. Possivelmente, em um passado sub-recente na escala do tempo geológico (Pleistoceno-Holoceno), a área do Planalto da Borborema onde se encontra Garanhuns sofreu repetidos desequilíbrios no seu sistema geomorfológico, gerando sucessivas incisões sobre o relevo, observáveis no entorno da atual mancha urbana da cidade de Garanhuns. Tais processos dinâmicos da paisagem certamente se deram a partir da interface clima/solo, sob o contexto de inúmeras oscilações climáticas cíclicas. A partir da contemplação deste cenário de heranças morfogenéticas provavelmente holo-pleistocênicas, constata-se que a influência do clima atual, preponderantemente subúmido, por si só não pode ser considerada como a única variável controladora do processo de reativação das paleofeições erosivas encontradas em Garanhuns, atualmente identificadas como voçorocas ativas.

Embora o papel dos eventos climáticos extremos seja importante neste tipo de avaliação, na escala atual pode se considerar o homem como o principal fator atuante sobre a redinamização de tais feições erosivas em Garanhuns, sobretudo em resposta ao processo de expansão urbana que, apesar de "formal", não observou as peculiaridades geomorfológicas, pedológicas e climáticas da área. Conclui-se que a avaliação dos impactos gerados sobre a geomorfologia da área, apenas sobre a perspectiva da má condução do processo de urbanização, atrelada à reativação erosiva, torna-se de difícil mensuração, já que determinados ambientes já são naturalmente vulneráveis.

Estudos dessa natureza indicam que a retomada da morfogênese em áreas urbanas pode ser considerada um processo azonal, assim como postulam Kertzan et al. (1995), Santoro e Fulfaro 
(1996), Pedro e Lorandi (2004), Ribeiro (2004), Modenesi e Hiruma (2004) e Silva et al. (2005), pois ocorre com frequência em diferentes pontos do país, sob diversas circunstâncias morfoclimáticas. No entanto, o elemento unificador, neste caso, decorre de que pesquisas com este enfoque abordam geralmente cidades de médio porte, onde a área rural começa a ser transformada pelo processo de expansão urbana. Não obstante, existem algumas peculiaridades locais, que conferem ao relevo de Garanhuns impedimentos notáveis ao estabelecimento de habitações populares. É objetivo deste trabalho enunciá-las.

O sítio urbano da cidade se caracteriza como uma série de superfícies de cimeira, tabulares, com rupturas de gradiente convexas, a partir das quais os fluxos superficiais não canalizados convergem em diversas cabeceiras de drenagem de primeira ordem, efêmeras e intermitentes. Logo, os principais problemas decorrentes da expansão do assentamento urbano referem-se à retomada erosiva e regressão destas cabeceiras. Neste contexto de investigação geomorfológica, o presente trabalho tem como objetivos a realização de um mapeamento geomorfológico e morfodinâmico em escala espaçotemporal, buscando estabelecer uma relação mútua entre gênese das unidades de relevo, materiais que as compõem e fluxos de energia.

\section{Localização da área de estudo}

A área selecionada abrange uma superfície aproximada de $100 \mathrm{Km} 2$, delimitada pelos paralelos $8^{\circ} 51^{\prime} 37^{\prime \prime} / 8^{\circ} 55 ' 40 " \mathrm{~S}$ e os meridianos $36^{\circ} 26^{\prime} 06^{\prime \prime} / 36^{\circ} 30^{\prime} 52^{\prime \prime} \mathrm{W}$, estando quase inteiramente dentro do limite municipal de Garanhuns, região Agreste do estado de Pernambuco. Sua escolha devese principalmente pela situação topográfica de cimeira tabular do Planalto da Borborema e limites de expansão do sítio urbano em transição para os domínios de uso rural (Figura 1). 


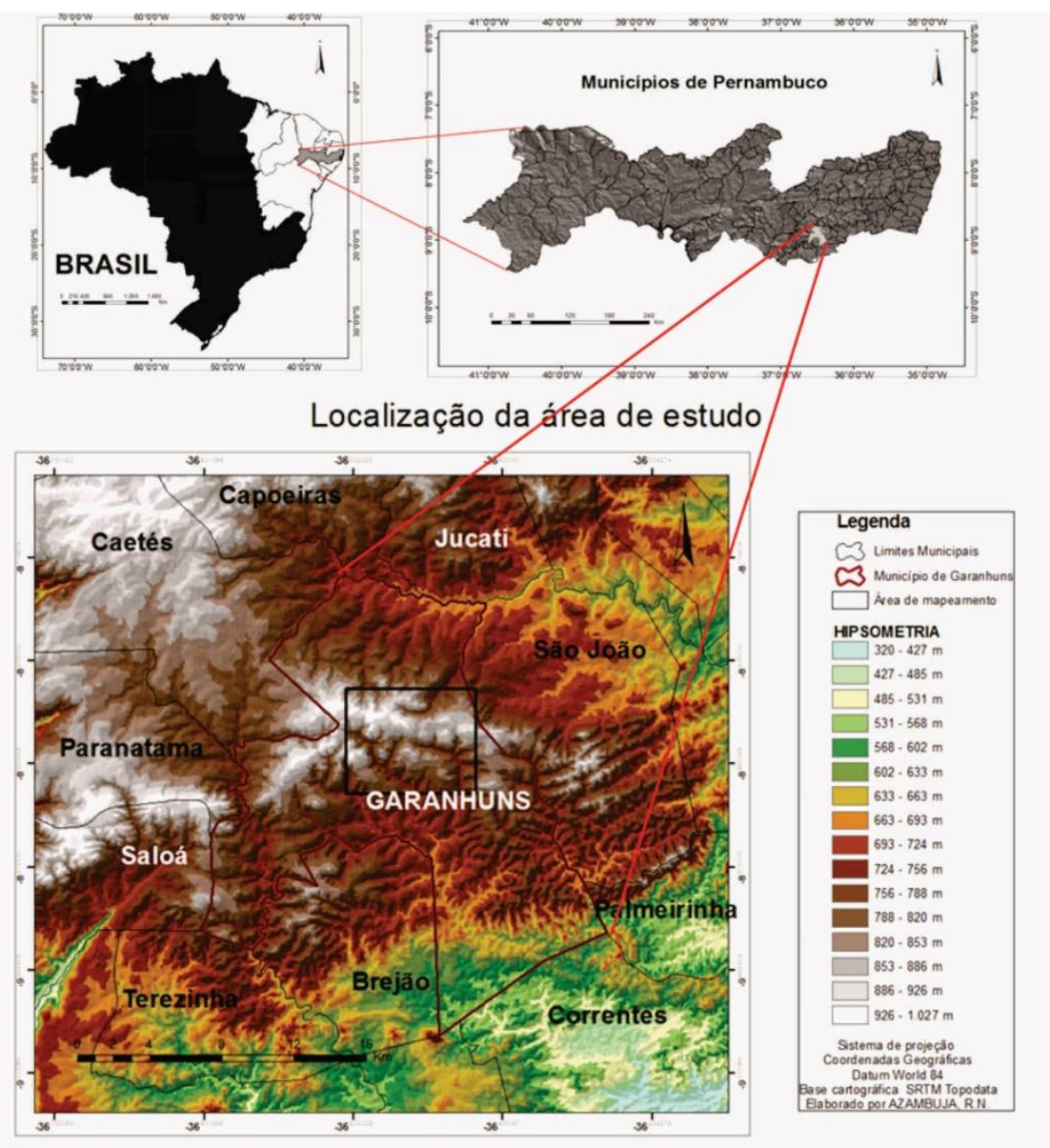

Figura 1. Localização da área de estudo.

\section{Características regionais}

Geologicamente o município de Garanhuns encontra-se sobre o cinturão orogênico meso-proterozóico da Província Borborema. Dividida por uma estrutura principal denominada Lineamento Pernambuco, a região de Garanhuns insere-se sobre a porção sul do Lineamento, descrita por Santos (apud CPRM, 2001) como domínio Externo Meridional, no qual está presente o terreno Pernambuco-Alagoas. Ocorrem duas unidades principais na área mapeada. Sobre o núcleo urbano e entorno (área principal) está assentado o Complexo Cabrobó, constituído por uma sequência clástica Vulcano-sedimentar continental. Costa Filho (1978) destaca a ocorrência sobre a área de quartzitos fortemente intemperizados que se sobrepõem discordantemente à unidade mesoproterozóica, definindo-a como principal representante do Complexo. Na outra unidade, localizada ao redor desta faixa, ocorre a presença do Complexo Belém de São Francisco. Este é composto predominantemente por ortognaisses e migmatitos com restos de supracrustais (CPRM, 2001). 
Por se encontrar em altitudes de 700 a 950 m em média, os solos de Garanhuns possuem dois tipos de derivação. O primeiro proveniente do intemperismo dos quartzitos in situ e o segundo do transporte e deposição, gerando, por vezes, solos alóctones. Na posição de topo de paisagem são encontrados com frequência os Latossolos Amarelos e Argissolos. Ambos apresentam perfis profundos, sendo os Latossolos constituídos de horizonte B latossólico e os Argissolos com B textural. Entretanto, um fator importante sobre estes tipos de solos diz respeito ao seu caráter herdado. A não funcionalidade dos Latossolos distribuídos pela área de estudo deve-se às condições climáticas atuais, menos úmidas que a de tempos passados, repercutindo em uma nova atuação pedogênica. De acordo com Azambuja (2007), este fato tem corroborado para a perda progressiva de argilas nos Latossolos ao limite NO da área de ocupação, bem como sobre os Neossolos Regolíticos, de forma mais extensiva, tornando-os incoesos.

A posição de topo e proximidade do rebordo oriental no contexto do Planalto da Borborema confere à área de Garanhuns destaque pela diferenciação do sistema climático de seu entorno. Assentado a uma altitude que varia entre 850 e 1.030 m, o perímetro urbano de Garanhuns, bem como seu entorno, possui um clima do tipo mesotérmico do tipo Csa, com chuvas de outono e inverno segundo a classificação de Köppen. A temperatura média anual encontra-se em torno de $20^{\circ} \mathrm{C}$. Durante o inverno as temperaturas podem atingir uma queda para menos de $17^{\circ} \mathrm{C}$, com mínima absoluta de $10^{\circ} \mathrm{C}$. No verão as máximas absolutas chegam a $36^{\circ} \mathrm{C}$. A precipitação média anual atinge em torno de 908,6 mm. As cotas máximas que podem ultrapassar $100 \mathrm{~mm}$ por sua vez ocorrem em dois picos anuais, no bimestre Março-Abril, e no trimestre Maio-Junho-Julho (NIMER, 1989).

\section{Compartimentação geomorfológica da área}

Embora até meados da década de 50 do século passado o Planalto da Borborema tenha sido interpretado como evolução de um bombeamento regional a partir do Cretáceo, a compreensão acerca dos compartimentos morfoestruturais somente foi elucidada por Czajka (1959). Através da interrelação entre lineamentos estruturais de direção E-W (Lineamento Pernambuco) e alinhamentos frequentes de direção WSW-ENE de serras e depressões, o autor supracitado identificou dois eixos de 
arqueamentos principais. O primeiro é encontrado na direção NNE-SSW no estado de Pernambuco pelos patamares de Arcoverde com serras e cimeiras a $1.100 \mathrm{~m}$ e Garanhuns com topo a 1.000 m. 0 segundo e mais expressivo seria constituído por serras alongadas de direção W-E, culminando na Serra da Baixa Verde-PE com topo de $1185 \mathrm{~m}$ e Teixeira-PB, $1.197 \mathrm{~m}$.

Sendo assim, a formação do Planalto da Borborema, de acordo com Mabessone \& Castro (1975), explica-se por uma fase de degradação e respectivo aplainamento a partir da reativação Wealdeniana, estruturando grande pacote de sedimentos entre o Albiano e Oligoceno. Consecutivamente, com o início de um soerguimento epirogênico lento a partir do Oligoceno Superior, sob este pacote deu-se lugar a um grande abaulamento culminando durante o Plioceno Inferior na elaboração da superfície Sulamericana, regionalmente reconhecida por esses autores como nível Borborema, proposta por King (1956) para as demais áreas do Brasil oriental. Trata-se, portanto, de um relevo que através da flexura do bloco continental sofreu soerguimento tectônico e repetidas fases de aplainamento.

Sobre este mosaico, a montante dos degraus de arqueamento, decorrentes de esforços transpressivos e distensivos, está assentado o Planalto de Garanhuns, estruturado por uma sequência quartzítica sobre embasamento gnáissico do Terreno Pernambuco-Alagoas. "Pode-se considerar a área de Garanhuns strictu senso como 'planalto', constituindo o único ressalto deste largo eixo de arqueamento da Borborema denominado de patamar erosivo de Garanhuns" (Correa, 2001).

A compartimentação geomorfológica da área em apreço engloba as seguintes unidades: o patamar erosivo com área de cimeira entre 850 e 950 metros (incluindo a superfície somital no morro do Magano de 1024m), patamares de dissecação pedimentar a 750-700 e 650-600 metros, um pequeno conjunto de serras alongadas (cristas) de direção ENE/WSW, além de modelados de dissecação poli convexa a $700 \mathrm{~m}$ de altitude ao sul das cristas (AZAMBUJA, 2007). Para uma melhor visualização dos compartimentos acima enunciados faz-se necessário apresentar um mapa geomorfológico da área, sobretudo porque alguns compartimentos de topos notavelmente planos se circunscrevem a partir de determinadas cotas altimétricas (figura 2). 

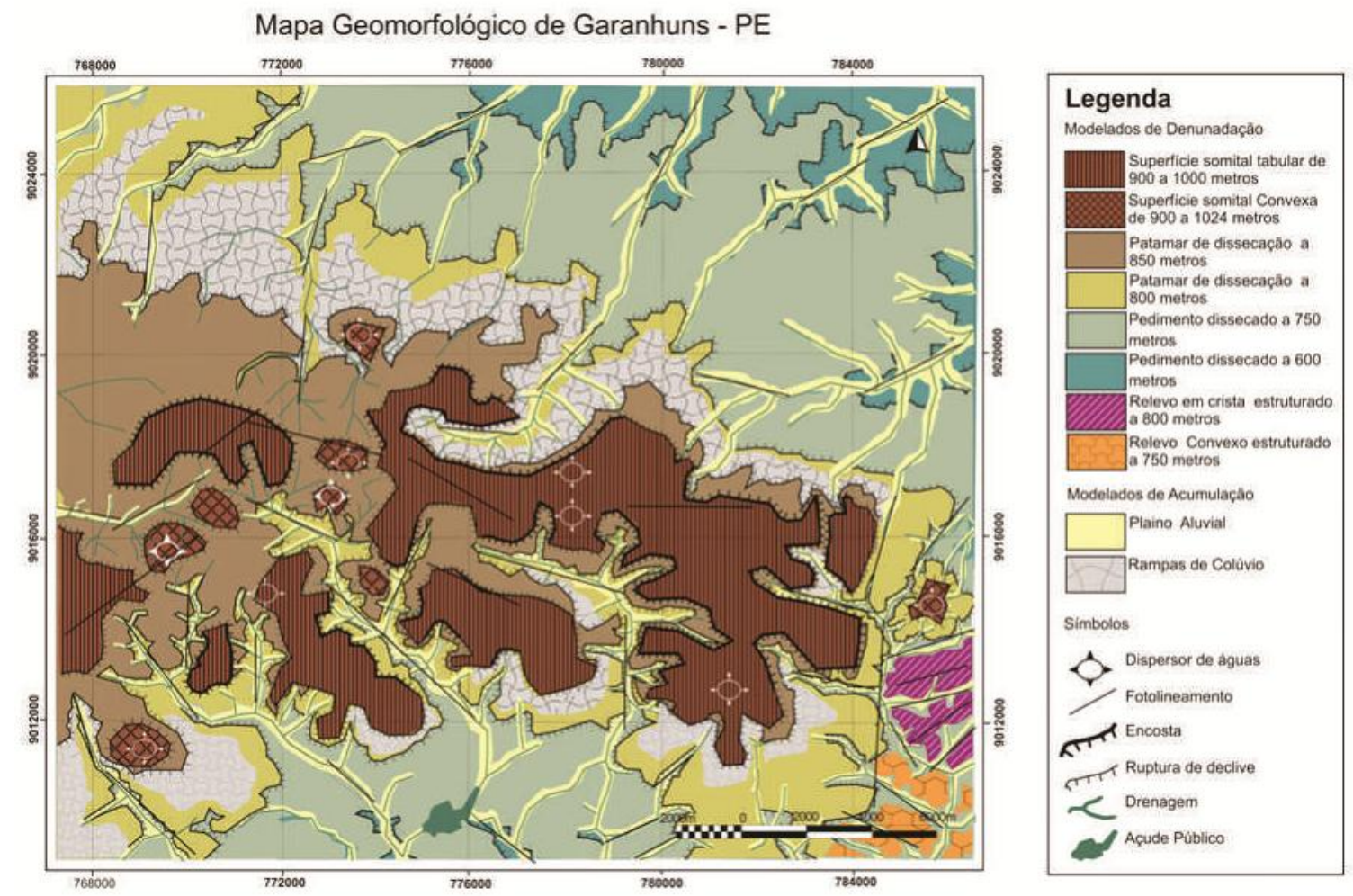

Figura 2. Mapa geomorfológico da área de estudo (AZAMBUJA, 2007).

\section{Elementos denudacionais}

Topo: a área urbana de Garanhuns e quase sua totalidade encontra-se sobre o compartimento de topo tabular. Está estruturado sobre uma altitude que varia entre 800-950 metros e possui ora rupturas de declividade convexa, ora retilínea, apresentando dissecações que variam de 50 a 100m entre topo e fundo de vale. Com frequência, este tipo de relevo apresenta-se fortemente dissecado sobre as unidades de encosta, por vezes com registros de extensas paleoincisões estabilizadas pela cobertura vegetal (fig. 03) (AZAMBUJA, 2007). 


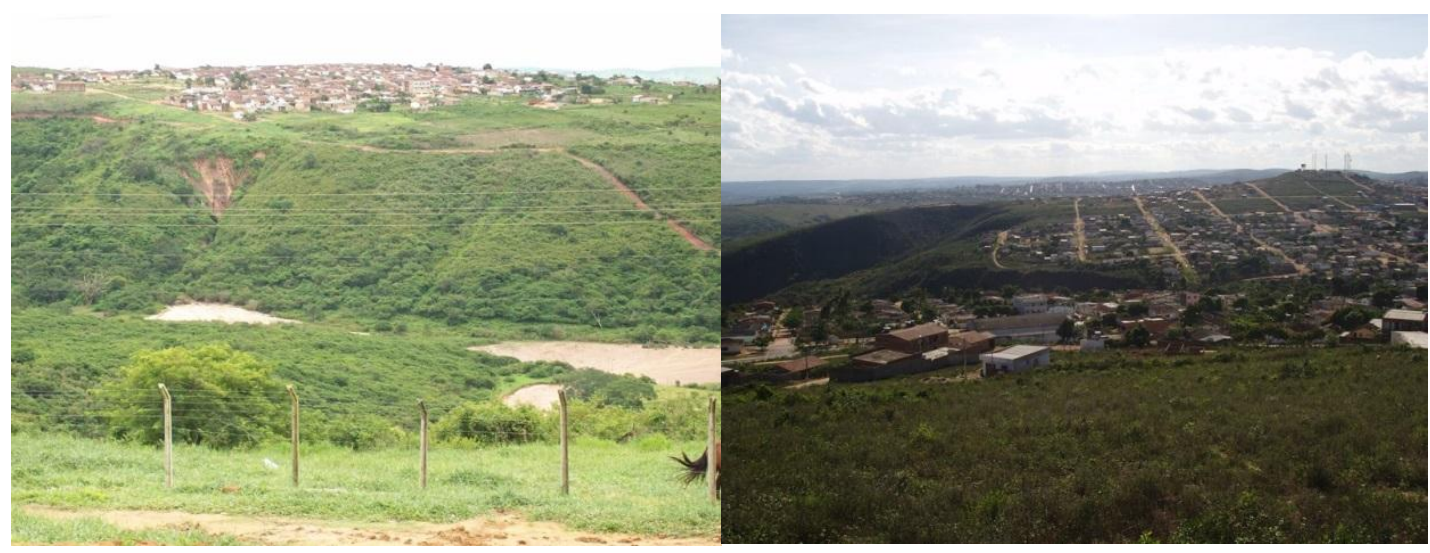

Figura 3. Compartimento de Topo Tabular com ocorrência de rupturas de declividade convexa na COHAB III (à esquerda) e ruptura retilínea na COHAB I (à direita).

Vertentes ou Encostas: Apresentam com frequência três tipos de ruptura de declividade sobre as áreas em questão: as vertentes retilíneas, côncavas e convexas. De forma geral, as vertentes retilíneas estão associadas às formas côncavas em posição inferior da encosta, predominando as cicatrizes de deslizamento, feição esta ubíqua ao longo do perímetro urbano. A ocorrência na área do quartzito Garanhuns subordinado a alinhamentos estruturais do mesoproterozóico, como verificado por Modenesi (1980) em trabalho sobre intemperismo e morfogênese no Planalto de Campo dos Jordão, exercem forte controle sobre o modelado no entorno da mancha urbana de Garanhuns. A progressiva remoção de cobertura vegetal nas áreas de cabeceira sobre estas áreas torna este compartimento altamente susceptível às ações antrópicas. Assim, as formas côncavas facilitam a convergência de águas, induzido à formação de sulcos e voçorocas, constituindo-se ao mesmo tempo como área de erosão e aporte de sedimentos, como referido por Resende (apud Ribeiro, 2004). Modenesi-Gauttieri \& Hiruma (2004) definem a associação destes dois tipos de vertente como anfiteatros de erosão com predomínio de as cicatrizes de voçorocas e deslizamentos (figura 4).

As feições de vertentes convexas ocorrem com maior frequência sobre as porções meridionais e setentrionais dos patamares de dissecação de 650 e $750 \mathrm{~m}$, onde o relevo é do tipo colinoso. De forma geral, tais vertentes possuem altitudes entre interflúvio e vale de 30 a $50 \mathrm{~m}$ e tendem a funcionar como áreas dispersoras de água, associadas à ocorrência de erosão laminar uniforme predominantemente sobre áreas de uso agrícola (AZAMBUJA, 2007). 


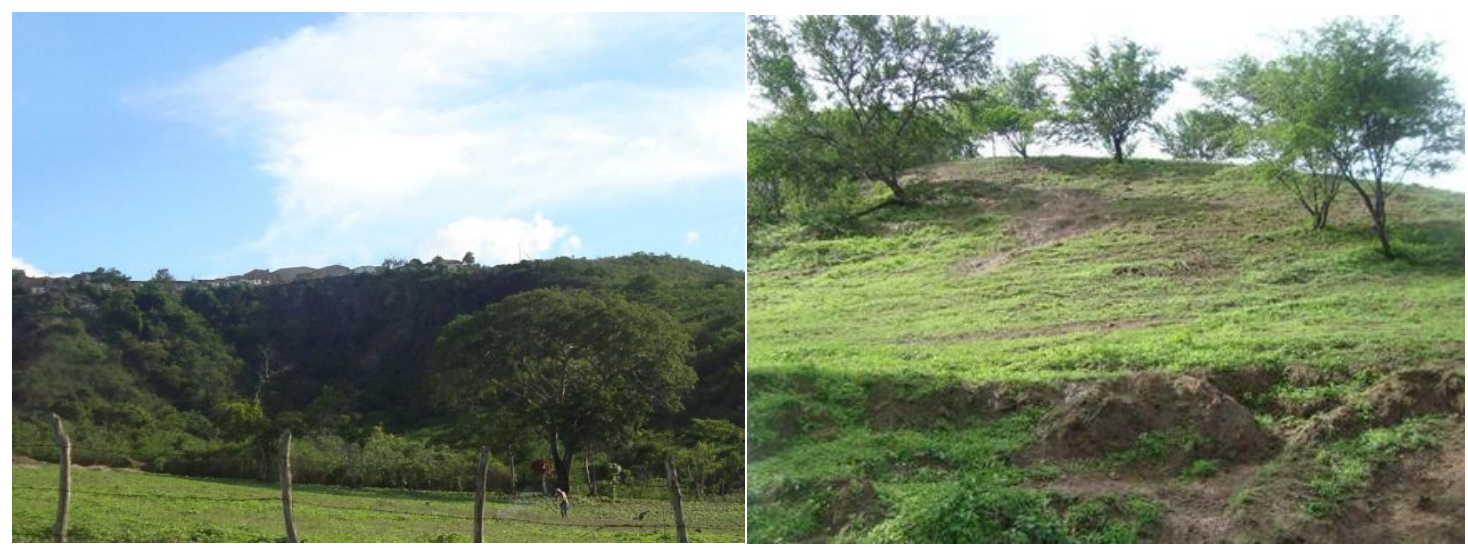

Figura 4. Encosta retilínea com ocupações irregulares sobre o ângulo de ruptura da encosta (esquerda) e encosta convexa em áreas de uso rural com erosão laminar (a direita).

\section{Elementos denudacionais}

Rampas de Colúvio - As vertentes estruturadas em rampa de colúvio são consideradas como elemento de acumulação subrecente. Estas são formas comuns sobre as áreas de transição entre encosta íngreme e terraços fluviais. Sua origem deve-se a sucessivos processos morfogenéticos pontuais, responsáveis pela remobilização de regolito a jusante de tais encostas. São rampas de ondulação suave que adquirem destaque pela coalescência de vários depósitos coluviais (figura 5) Devido à heterogeneidade de seus sedimentos, muitas vezes estas áreas configuram-se como instáveis, podendo em certos estágios se transformarem em nova área fonte de sedimentos, quando fortemente erodidas (AZAMBUJA, 2007).

Plaino Aluvial - este compartimento ocorre em áreas baixas e planas, ao longo dos tributários e do próprio Riacho Rua Nova a SSE da área urbana e ao longo do vale do Riacho São Vicente a NNE, sobre altitudes que variam entre 700 e $800 \mathrm{~m}$. Frequentemente é limitado por encostas de rampas de colúvio que formam truncamento sobre as áreas de terraços propriamente ditas (figura 5). De acordo com Azambuja (2007), devido a sua expressão espacial, esta faixa nem sempre consegue ser representado pelo mapeamento em escala de semidetalhe, considerando-se em sua grande parte como margens dos cursos fluviais na área de estudo. 
Terraços - As unidades de terraços encontram-se preenchidas por material alúvio-coluvionar cortadas por drenagens intermitentes da área. Correspondendo ao Ciclo Paraguaçu de King (1959), em sua grande parte os terraços são ocupados pela agricultura de gênero alimentícios, no entanto sua limitada expressividade espacial não permite discerni-los no mapa geomorfológico. Portanto, para fins de mapeamento, esta unidade está representada de forma indivisa, junto ao plaino aluvial.

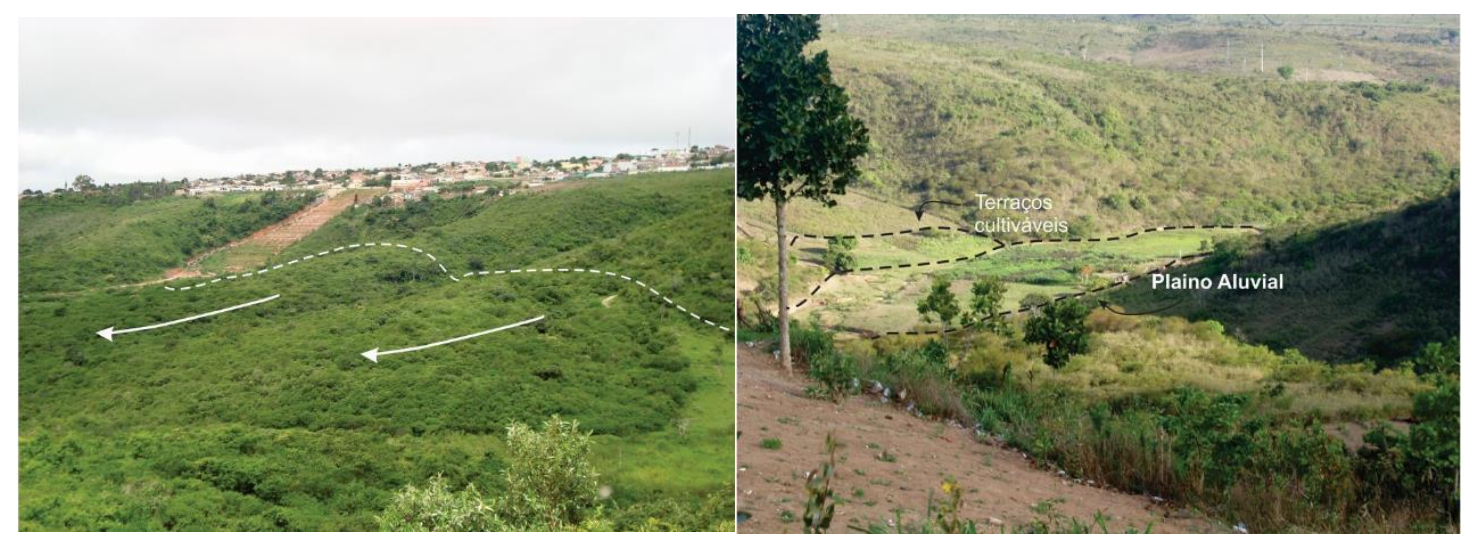

Figura 5. Modelados deposicionais no entorno urbano de Garanhuns. À esquerda, rampas de colúvio e à direita plaino aluvial e terraços utilizados pela agricultura.

\section{FUNDAMENTAÇÃO TEÓRICA}

Ao se realizar uma análise geomorfológica, devem-se levar em conta as forças ativas e passivas oriundas dos processos internos e externos do relevo, sobre o qual se dão as transformações decorrentes das atividades humanas. Por esse motivo, Ross (2005) afirma que a geomorfologia, nos estudos ambientais, está sustentada sobre as ciências naturais, ainda que possua forte vínculo com as ciências humanas, servindo, dessa maneira, como suporte para o entendimento das sociedades humanas que se estruturam, extraem recursos e organizam o espaço físico territorial sobre ambientes originalmente naturais.

Sobre o foco dos estudos ambientais, o conhecimento acerca dos aspectos geomorfológicos pode servir tanto como diagnóstico de situações, quanto como subsídio para o planejamento territorial. 
Estudos relacionados à morfodinâmica tiveram sua gênese na teoria dos geossistemas, introduzida por Chorley (1962) nos estudos geomorfológicos. A teoria geossistêmica levou em consideração critérios de capacidade integrativa sobre a realidade complexa e ainda o estabelecimento de diversos tipos de sistemas, com grande relevância para os estudos relacionados à geografia física.

Chorley e Kennedy (1968 apud Christofoletti, 1999) destacaram o reconhecimento dos sistemas morfológicos, sequenciais, de processo-resposta e controlados, como os mais importantes na investigação ambiental. O funcionamento dos sistemas morfológicos fechados ou abertos, em geral, é considerado como resposta ou ajustamento de fluxos de energia e matéria do sistema em sequência. Como exemplo, verifica-se sobre a relação entre rede de drenagem, encostas e instalação de equipamentos, o estabelecimento de variáveis que afetam diretamente a geometria e composição do relevo.

De acordo com Corrêa (1997), o mapeamento geomorfológico de detalhe tem como principal objetivo investigar as formas, defini-las e elucidar suas funções dentro do sistema. Entretanto, outro tipo de exame deve ser realizado, no qual sejam contemplados os processos ocorrentes, em particular das taxas de operação dentro da geomorfologia dinâmica.

Tendo em vista esse quadro complexo entre processos de origem natural e antrópica, Tricart (1977), ao estabelecer as unidades ecodinâmicas, sugere que a paisagem seja analisada pelo seu comportamento dinâmico, partindo de uma compartimentação em unidades de paisagem ecodinâmicas. Para o referido autor, a morfodinâmica é o elemento determinante dos processos, dependendo diretamente do clima, relevo, natureza da rocha, solos, cobertura vegetal, dentre outros fatores. Ao dividir as unidades morfodinâmicas em três categorias, Tricart (op. Cit) propôs a designação para o grau de estabilidade entre os meios estáveis, intergrades e fortemente instáveis. Passando obrigatoriamente pelo inventário do quadro natural, em seus diversos estágios de antropização, Ross (2005) complementou esta proposta, traduzindo-a em um diagnóstico objetivo, representando o grau de sensitividade da paisagem. 
Além do enfoque em estabelecer níveis de estabilidade para a paisagem geomorfológica, estudos relacionados à morfodinâmica baseiam-se na fisiologia da paisagem afim de compreender os processos morfoclimáticos e pedogênicos atuais. Casseti (2006) complementa com a afirmativa de que este tipo de abordagem envolve a situação do relevo atual, fruto das relações morfodinâmicas resultantes da consonância entre os fatores intrínsecos (inerentes ao próprio relevo) e os fatores extrínsecos, com ênfase no uso e ocupação do modelado enquanto duas forças antagônicas.

Portanto, ao mesmo tempo em que o estudo da fisiologia da paisagem tem sua ótica focada sobre o momento histórico atual, o mesmo não deixa de levar em consideração o registro dos mecanismos associados ao tempo geológico, responsável pela evolução do relevo expresso sobre a topografia e seus respectivos depósitos correlativos. A ocorrência de depósitos correlativos sobre a paisagem resulta de relações processuais que variam de curto a longo prazo. Porém, a apropriação do relevo pelo homem, seja como recurso ou suporte, tem determinado modificações substanciais sobre o substrato de evolução natural.

\section{PROCEDIMENTOS METODOLÓGICOS}

O mapeamento morfodinâmico foi elaborado em três momentos distintos através de fotografias aéreas em escala de 1: 70.000 (CPRM, 1965), 1: 25.000 (FUNTEPE, 1982) e imagem de satélite em mosaico de 1:25.000 (Google Earth, 2006 e 2013). Este tipo de avaliação teve como objetivo identificar as mudanças ocorridas em uma escala de tempo histórico. Foi gerada, ainda, uma base cartográfica temática contendo mapas de geologia, solos e hidrologia, extraídos de dados da CPRM (2005) e ZAPE (2000) com o intuito de categorizar os diversos layers responsáveis pela resposta morfodinâmica da área de estudo. Como auxílio à interpretação dos fatos geomorfológicos e processos operantes em cada período de análise, dados climatológicos foram compilados e analisados.

Os dados topográficos foram obtidos através de imagens SRTM com resolução de 90m, interpoladas pelo projeto TOPODATA para resolução de 30m, permitindo a modelagem, interpretação e análise do 
relevo com a extração de dados planialtimétricos (MDE), bem como da compartimentação do relevo local. O material em questão é disponibilizado pelo Banco de dados Geomorfométricos do Brasil do INPE.

A reunião dos dados cartográficos e topográficos subsidiou a formação de um SIG para a aplicação do método de análise ecodinâmicas proposto por Tricart (1977). Nessa perspectiva, a realização de análise de unidades ecodinâmicas integra o conceito de ecossistema. Baseado em uma lógica de sistema ambiental, os diversos componentes inerentes à dinâmica de fluxos de matéria e energia neste tipo de observação representam uma avaliação significativa do impacto causado pela inserção de tecnologia humana dentro do ecossistema. Ainda afim de complementar esse tipo de avaliação, foi adotada a técnica de obtenção do grau de fragilidade da paisagem proposto por Ross (2005).

A elaboração final dos mapas foi realizada através da utilização do software Arc Gis 9.3 do Departamento de Ciências Geográficas da UFPE.

A partir de análises preliminares de elaboração do SIG, foram selecionadas as áreas com maior probabilidade de ocorrência de processos erosivos em estágio avançados e, consecutivamente, trabalho de campo para síntese e coleta de materiais.

Durante o trabalho de campo foram realizadas observações acerca do comportamento geomorfológico em áreas de expansão urbana compondo a caracterização de depósitos recentes de encostas, bem como a relação entre geometria do relevo e processo erosivo, baseado em trabalhos realizados por Modenesi (1992) Modenesi e Toledo (1993) e Modensei-Gauttieri e Hiruma (2004), bem como a verificação de processos provocados por intervenções antrópicas, tais como aterramentos de áreas atingidas por processos erosivos, cicatrizes de erosão reativadas pelo incremento do fluxo superficial concentrado de chuva e efluentes em geral, decorrentes de impermeabilização dos solos e baixa infraestrutura urbana das áreas atingidas pelos problemas ora expostos. 
Em virtude de várias áreas analisadas demonstrarem uma profunda descaracterização, decorrente de inúmeras tentativas de solucionar os problemas erosivos de todo entorno urbano, foram selecionadas apenas três áreas para amostragem de sedimentos localizadas no setor Noroeste da área de estudo. Trata-se de um vale onde convergem várias cabeceiras de drenagem de primeira ordem e encontra-se a antiga incisão da voçoroca da BR423. Foram coletadas as seguintes amostras: CVG - cabeceira da Voçoroca da BR423; NCG - cabeceira localizada no bairro COHAB III e LCG - leque alúviocoluvial da Voçoroca da BR 423.

Os ensaios de laboratório, tais como granulometria, morfoscopia, análise geoquímica e mineralogia das argilas, tiveram por objetivo realizar a interpretação dos dados sedimentológicos das respectivas áreas relacionadas aos processos recentes de redinamizarão erosiva.

\section{RESULTADOS E DISCUSSÃO}

\section{Expansão urbana de Garanhuns}

A dinâmica de distribuição da população no espaço urbano é regida fundamentalmente pelo "valor do solo". Fatores secundários, como paisagísticos ou econômicos, constituem relação direta com o fator renda, o que induz consequentemente a relação entre valor do solo e fatores sociais. Estando o espaço urbano de Garanhuns fortemente condicionado à sua morfologia, relevo, solo e eixos viários 'subprimários', restam às populações de baixa renda instalar-se em locais de qualidade inferior, seja em relação às edificações, seja na infraestrutura instalada. Sob o ponto de vista de uma abordagem ambiental inadequada, o poder legislativo tem imposto à população de menor poder aquisitivo o enfretamento de problemas como: leito das ruas erodidas, ruas de elevada declividade longitudinal sem qualquer tipo de pavimentação ou proteção, que facilmente se transformam em voçorocas, drenagens desarranjadas e sistemas de edificação comprometidos. Por outro lado, nos últimos anos outro fenômeno vem ocorrendo sobre os limites físicos da área urbana já estabelecida: a construção de terraços nas bordas do tabuleiro. Conduzidas por interesse especulativo e construção de condomínios de luxo, empreiteiras e construtoras têm contribuído para o aumento da susceptibilidade do solo urbano em Garanhuns. 
Ao analisar o movimento de expansão urbana, nota-se que as áreas direcionadas a reservas de expansão encontram-se grosso modo sobre áreas geomorfologicamente instáveis (figura 6).

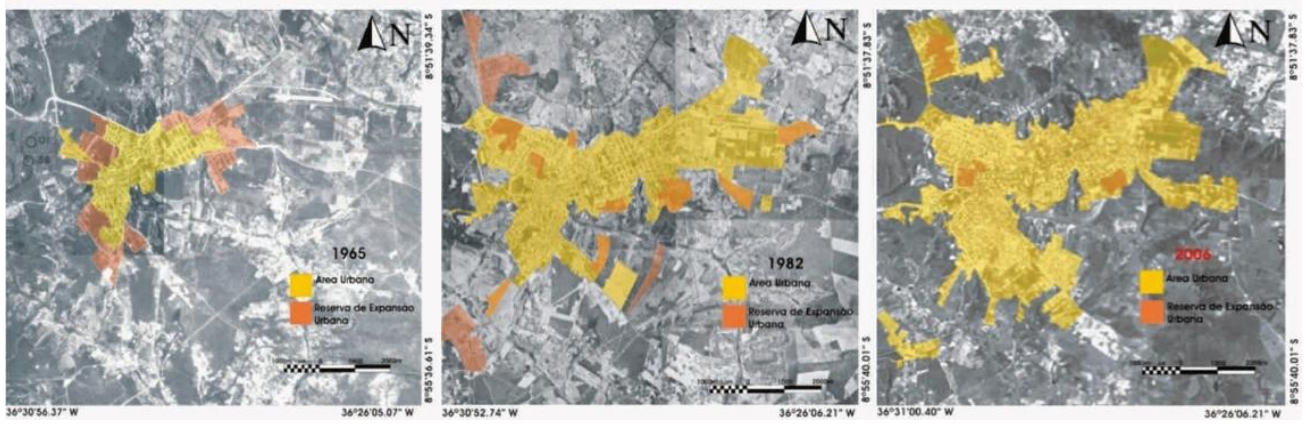

Figura 6. Processo de expansão urbana em Garanhuns-PE pontuando os anos de 1965, 1983 e 2006.

\section{Análises dos parâmetros estatísticos}

Através dos resultados obtidos em laboratório, foi possível caracterizar a natureza dos depósitos analisados de forma qualitativa e quantitativa. A correlação dos parâmetros sugere que os sedimentos da LQG representam um tipo de transporte proximal, com predomínio de grãos pouco trabalhados (de anguloso a subanguloso) somando 70\% da amostra. Grande parte do transporte também se dá por tipo fluido, já que $72 \%$ da amostra apresentaram polimento em seus grãos. LQG também foi a amostra que apresentou a maior proporção de grãos de baixa esfericidade, porém não muito diferente das amostras restantes, podendo ter uma forte ligação com material de origem, como o Quartzito Garanhuns.

Dissertando sobre os resultados dos parâmetros de análise granulométrica, pode-se dizer quanto ao grau de seleção que as amostras apresentaram sedimentos muito pobremente selecionados e pobremente selecionados (Tabela 1). Valores de desvio padrão acima de 2 foram encontrados para as amostras CVG e NCG, atribuindo um caráter de seleção muito baixa para ambas amostras. A pequena diferenciação para a amostra LQG deve-se ao fato de o sedimento transportado e depositado no local ter sofrido progressivo efeito de seleção, porém ainda muito incipiente, apresentando-se mal selecionado de acordo com os resultados obtidos. 


\begin{tabular}{llcc}
\hline Amostra & \multicolumn{1}{c}{ Seleção } & Assimetria & Curtose \\
\hline CVG & 2,5 Muito pobremente selecionada & $-0,06$ Assimetrianegativa & 0,93 mesocúrtica \\
LQG & 1,0 Pobremente selecionada & 0,1 Assimetria positiva & 0,75 platicúrtica \\
NCG & 2,3 Muito pobremente selecionada & 0,3 Assimetria muitopositiva & 0,98 mesocúrtica \\
\hline
\end{tabular}

Tabela 1. Parâmetros estatísticos dos sedimentos por área de amostragem.

Em se tratando dos resultados de assimetria, que segundo Corrêa (2001) reflete o quanto a distribuição varia em relação à curva normal (curva simétrica), esta fornece indicações sobre a natureza do fluxo dos sedimentos, se unidirecional (assimetria positiva) ou bidirecional (negativa). De acordo com os resultados obtidos entre positivos e muito positivos para LQG e NCG, respectivamente, verificou-se uma concentração de grãos mais grossos e uma distribuição polimodal. Ao contrário, CGV apresentou valor negativo de assimetria, condizente com o resultado obtido por Camargo Filho e Bigarella (1998) na bacia do Rio Bananas, no Brasil meridional. A combinação nos resultados de assimetrias muito negativas e sedimentos muito pobremente selecionados confirma uma forte hidrodinâmica de encosta, como naturalmente ocorre sobre estes tipos de sedimentos.

Foi percebido ainda o predomínio de classes modais arenosas para as amostras LQG e NCG. Para o primeiro caso pode-se dizer que o fator hidrodinâmico local rege um forte controle sobre o transporte de classes finas, resultando em uma distribuição predominantemente arenosa (Tabela 02). Em NCG este parâmetro reflete um controle mais climático que propriamente um predomínio de fluxo (Tabela 02). A área de expansão urbana, localizada a norte da cidade, particularmente no bairro de Dom Helder Câmara, apresentou variações no comportamento climático, diferentemente do predominante no município, verificado, sobretudo, pelo predomínio dos Regossolos, em franco processo de perda de material fino (silte e argila).

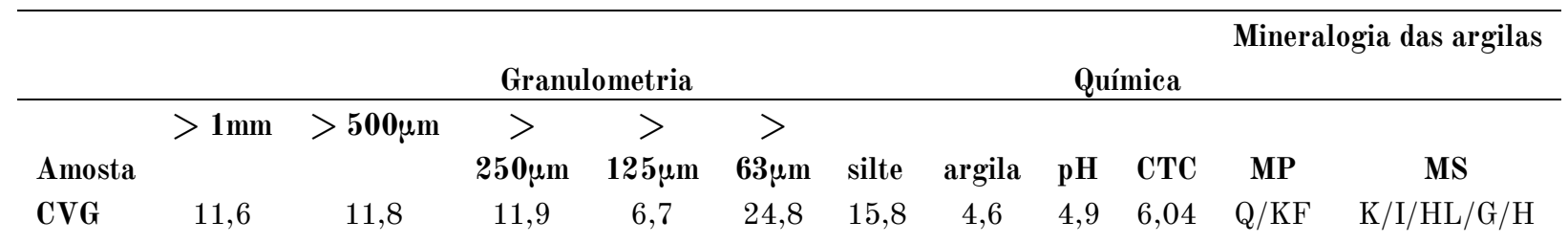




$\begin{array}{llllllllllll}\text { LQG } & 31,2 & 34,9 & 19,7 & 9,4 & 3,0 & 1,4 & 0,4 & 6,8 & 3,72 & \mathrm{Q} & \mathrm{K} / \mathrm{S} / \mathrm{MG} / \mathrm{G} / \mathrm{H} \\ \text { NCG } & 19,1 & 21,5 & 18,8 & 13,8 & 4,9 & 19,3 & 2,6 & 4,6 & 6,84 & \mathrm{Q}-\mathrm{KF} & \mathrm{K} / \mathrm{I} / \mathrm{G} / \mathrm{H}\end{array}$

Tabela 2. Distribuição granulométrica, propriedades químicas e mineralogia das argilas. $\mathrm{Mp}=$ minerais primários e $\mathrm{MS}=$ minerais supérginos. Q - quartzo, KF - K-feldspato (microclina), K - caulinita, I - ilita, HL - haloisita, G - goethita, Hhematita, S - Saponita, MG - magnetita.

Com referência às propriedades químicas, foi verificado que os valores de $\mathrm{pH}$ acompanharam os valores de capacidade de troca catiônica (CTC). As áreas fontes com $\mathrm{pH}$ baixos indicam a predominância de ambiente ácido, enquanto em LQG o pH encontrado foi quase básico - 6,8. Este resultado demonstra que, de certa forma, vem ocorrendo na área em questão o acúmulo de sais provenientes da área fonte. Os valores de CTC muito baixos indicam para os depósitos residuais avançada perda dos minerais silicatados. No caso da amostra CVG, os sedimentos analisados demonstraram maior grau de intemperismo químico com uma relação silte/areia maiores que as demais amostras.

Em consonância com os resultados de $\mathrm{pH}$, as análises de mineralogia das argilas estabeleceram uma divisão entre ambientes de monossialização nas áreas de cabeceira e enriquecimento de argilas do tipo 2:1 na porção deposicional do leque aluvial. Predominou, sobre as áreas de cabeceira, a ocorrência de minerais ferruginosos, ora em estrutura caulínica, ora sobre a forma de óxidos e hidróxidos de ferro, como a Hematita (em menor proporção) e a goethita (mais abundante), refletido pelo intemperismo do K-feldspato ou minerais micáceos presentes no embasamento quartzítico.

A Haloisita, denominada como uma variação das caulinitas, também apresentou consideráveis proporções em CVG, indicando um maior acúmulo de Alumínio neste perfil. Em NCG não foram encontradas grandes variações de minerais do tipo 1:1. Entretanto, níveis de quartzo também foram encontrados em abundância em ambas as amostras, demonstrado pela boa reflexão dos picos e tamanho de fração $>1 \mu m$. 
No que diz respeito à amostra LQG, as condições hidrológicas de encosta têm favorecido a formação de minerais supérgenos particulares sobre o depósito de origem colúvio-aluvial. Ocorre sobre tal depósito a presença de argilominerais de do tipo 2:1, como a magnetita e a saponita (pertencente à família das esmectitas). Enquanto que a hematita e goethita ocorreram em menores proporções, a caulinita também apareceu neste depósito em maiores proporções.

\section{Análise da evolução espaço temporal}

A análise espaço temporal inicia-se em 1965. Embora este período coincida com a aprovação do Código Florestal n. 4.771, de 15 de setembro de 1965, desconhece-se qualquer tipo de medida em favor da manutenção de áreas de preservação em Garanhuns. Ainda assim, não foram identificados muitos processos de desestabilização nas áreas de entorno do perímetro urbano.

Em geral, as áreas voltadas para a expansão urbana no município de Garanhuns apresentaram-se como as mais instáveis geomorfologicamente. Ambientes qualificados como fortemente instáveis sobre o entorno da mancha urbana foram associados frequentemente a corte de estradas, próximos a áreas de ruptura de declive acentuada com exposição de solo. Sobre áreas de uso rural foram encontrados inúmeros processos de erosão laminar incipiente, associados em geral a culturas de curto ciclo e baixa densidade espacial. $\mathrm{O}$ fator atenuante neste caso esteve relacionado à presença de cobertura vegetal secundária sobre vertentes, na transição entre topos com pastagens e baixas vertentes sob policultura. A presença de cobertura vegetal sobre os solos confere aos ambientes de uso rural instabilidade moderada e, na sua ausência, forte instabilidade. Embora as áreas ocupadas por vegetação secundária arbustiva estejam associadas a terrenos de alta declividade, estas foram consideradas como as áreas de menor instabilidade neste período (figura 7).

A expansão urbana sobre as áreas de encostas, ocorrendo em concomitância a um forte evento de estiagem no ano de 1982, conduziu a tipos de ações antrópicas extremamente nocivas aos sistemas naturais neste período. Calcula-se que, após o forte evento de ENOS ocorrido nos anos de 1982-83, e durante a transição que se seguiu de um regime árido para um moderadamente úmido, a densidade de 
drenagem, a taxa de escoamento e a produção de sedimentos foram acentuadas até atingir seu novo patamar de equilíbrio. Ambientes anteriormente considerados moderadamente estáveis passaram à categoria de fortemente instáveis, devido, sobretudo, à ausência de cobertura vegetal, seja natural ou cultivada. Notou-se um aumento de solo exposto sobre as áreas de contato urbano rural e fragmentação da cobertura vegetal, concentrando-se está apenas nas áreas ripárias (figura 4). A frequente ocorrência de exposição de solo em áreas de uso rural contribuiu para o incremento da erosão laminar principalmente sobre altas declividades. Os ambientes classificados como de fraca instabilidade se restringiram apenas às áreas de encostas com presença de cobertura vegetal secundária e às áreas urbanizadas equipadas de forte infraestrutura (figura 8).

O interstício de 24 anos configurou-se em um complexo mosaico de arranjos morfodinâmicos para a área de Garanhuns. Após dois grandes episódios de ENOS nos anos de 1982-83 e 1997-99, a tendência de precipitação sofreu sensível aumento, sobretudo nos anos de 2002, 2004 e 2005. Este movimento de mudanças de signos sazonais e rápidas mudanças climáticas tem refletido em modificações no padrão de comportamento da geomorfologia processual atual da área de estudo. Apesar do movimento de expansão de áreas verdes sobre as encostas, não ocorreram modificações quanto ao redirecionamento de habitações das áreas de alto risco para áreas menos instáveis no ano de 2006. Este fato é demonstrado pelo contínuo descumprimento do código florestal por parte do poder público. Neste período verificou-se problemas frequentes relacionados a movimentos de massas e erosão linear no entorno da mancha urbana (figura 9). O possível aumento desta taxa provocou modificações irreversíveis na morfologia da paisagem. O exemplo maior foi a erosão regressiva de encosta que ocorreu sobre a BR 423entre os anos de 2004-2006, favorecendo a formação de vertentes retilíneas e, consequentemente, novos patamares de ruptura de declive, realimentando o processo erosivo.

As áreas de várzea ocupadas por uso rural apresentaram-se inteiramente colmatadas por sedimentos alúvio-coluvionares, atribuídos ao caráter de intermitência dos cursos de água e o alto aporte de sedimentos nas últimas quatro décadas. Apesar do tipo de uso se constituir menos agressivo ao 
ambiente, setores como estes deveriam permanecer como área de preservação rigorosa, já que sua caracterização morfodinâmica é de alta instabilidade devido à inconsolidação de seus depósitos recentes e sub recentes. Outro grave problema identificado foi a associação de técnicas agrícolas inadequadas às altas declividades, sobretudo onde ocorre uma tensão entre espaço de uso urbano e rural. Estipula-se que este tipo de conduta tem sido responsável pela exposição de solos sobre encostas em grande parte, proporcionando ao ambiente maior instabilidade.

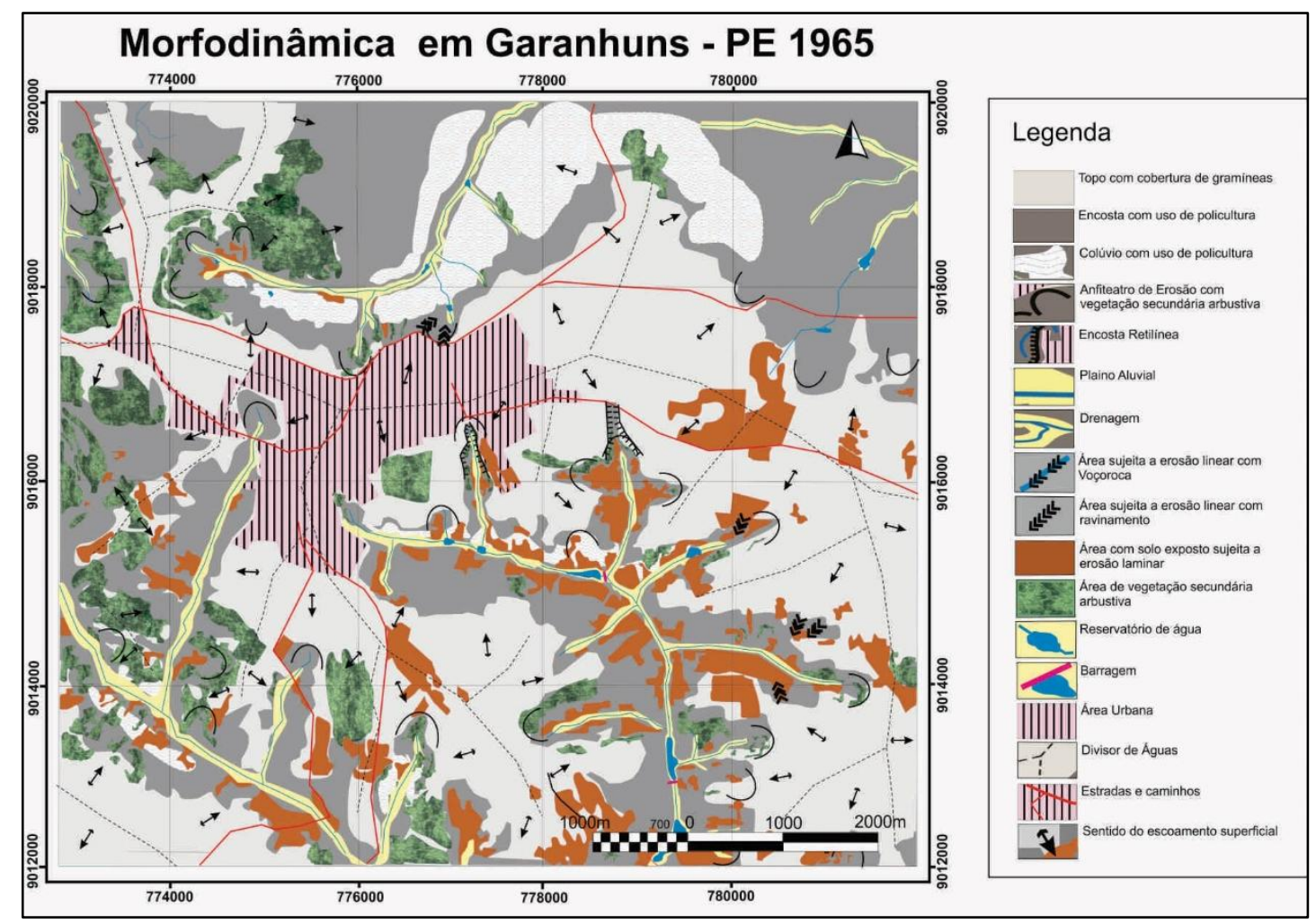

Figura \%. Morfodinâmica de Garanhuns em 1965. 


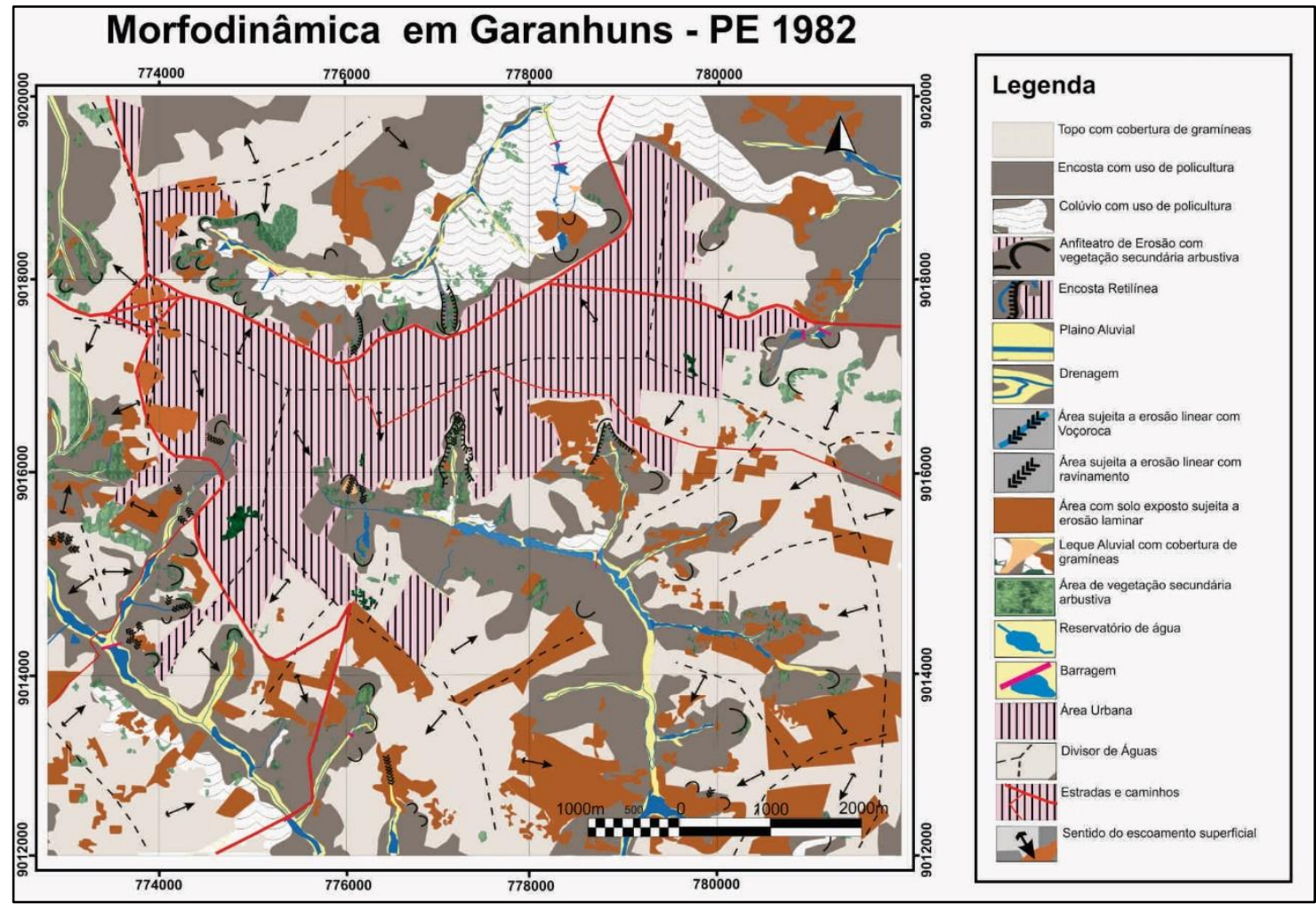

Figura 8. Morfodinâmica de Garanhuns em 1982.

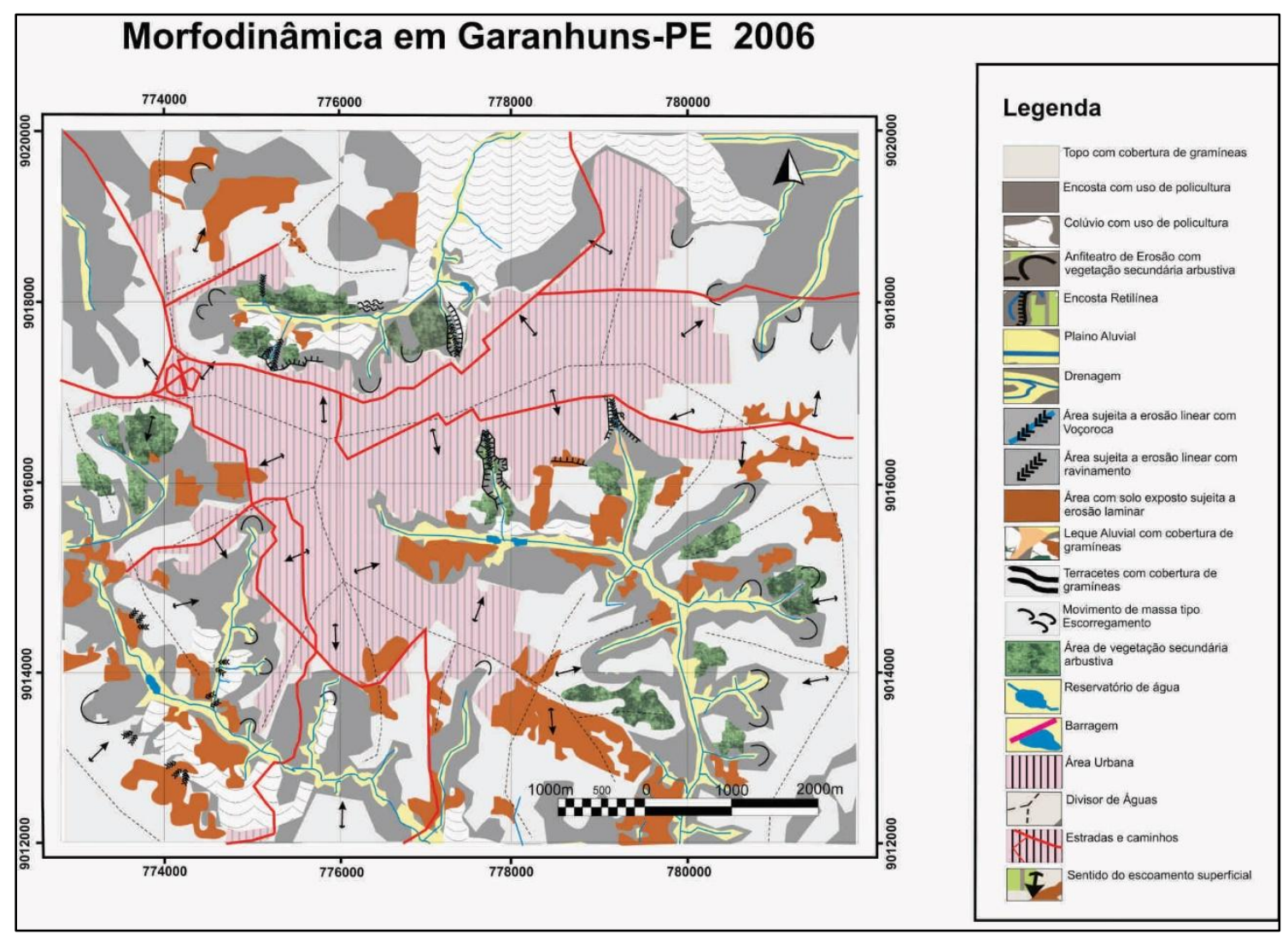

Figura 9. Morfodinâmica de Garanhuns em 2006. 


\section{Evolução das paleoincisões de Garanhuns}

Entre os anos de 2002 e 2006 a área urbana de Garanhuns sofreu inúmeras transformações morfológicas, decorrentes de reativações de paleovoçorocas. O caso mais notável neste período foi o de uma voçoroca localizada na BR 423, porta de entrada e saída de veículos da cidade, que segue em direção para o interior de PE, bem como aos Estados da BA e AL. Através do mapeamento morfodinâmico ora exposto, e da análise categórica espaço-temporal, foi verificado que este local de alta vulnerabilidade pouco foi contemplado por políticas de proteção permanente.

Evidências relacionadas à modificação do padrão hidrológico em nível local ao longo dos anos foram observadas, sobretudo em relação à porção basal da voçoroca. De acordo com tal análise, o eixo deposicional dos sedimentos provenientes desta encosta experimentou profundas alterações num espaço de tempo de 37 anos de progressiva remoção da cobertura vegetal nas cabeceiras e ocupação da área.

O aumento de taxas de sedimentos depositados no fundo do vale do Riacho São Vicente conferiu uma menor capacidade de transporte ao curso, devido a sua baixa competência e construção de inúmeros barramentos. De acordo com os resultados obtidos pela análise sedimentológica, as partículas experimentaram curto transporte até a baixa encosta, evidenciado pelo moderado grau de retrabalhamento dos grãos, com maiores porcentagens entre subangulosos e subarredondados. Sendo assim, foi realizada a esquematização de eventuais modificações sobre a geomorfologia da área em decorrência de variações de processos atuantes.

O esquema evolutivo baseado em Ruhe (1974) descrito in Oliveira e Meis (1985) (figura 10) foi adaptado para cinco estágios diferenciados com o objetivo de demonstrar a ocorrência de mudanças significativas em termos de processos superficiais e sub superficiais. Partindo do estágio I (figura 10 n.I), verifica-se a manutenção de certo equilíbrio sobre o ambiente de encosta. A cobertura vegetal ocupa toda área de maior suscetibilidade, mantendo estabilizada uma paleofeição erosiva, caracterizada 
por uma suave linha de drenagem de primeira ordem. Neste período, sobre os baixos pedimentos, a atividade antrópica se fez presente pela substituição de vegetação de porte arbóreo por gramíneas de pastagem. A incisão de uma linha de drenagem bem marcada sobre a área plana favoreceu a construção de uma pequena barragem, impedindo a livre circulação do material transportado pela drenagem. Acredita-se que este momento de estabilidade da encosta tenha ocorrido até meados da década de 70, quando se inicia o processo de rápida expansão urbana.

No momento II, a retirada de cobertura vegetal da área de cabeceira de drenagem expôs os solos à maior atuação dos agentes erosivos. Sobre o ambiente de encosta a condição de grande destacamento e baixo transporte dos sedimentos foi favorecida. Além do fornecimento de partículas para fora da zona de impacto, ocorreu a selagem da superfície, reduzindo a capacidade de infiltração e o incremento do escoamento superficial. Aplicando-se às características texturais do perfil CVG, a considerável proporção de partículas do tamanho silte - aliado à alta declividade da encosta - facilitou o destacamento e rápido transporte dos sedimentos.

A frequência de eventos pluviométricos intensos sobre estas encostas desprotegidas converteu a situação para um baixo destacamento e alto transporte das partículas do solo. O escoamento difuso rapidamente converteu-se para fluxos concentrados nas paleoincisões, dando origem ao ravinamento da área em questão (Figura 10 n.II). A construção de casas próximas à linha de ruptura de declividade contribuiu fundamentalmente (pelo fornecimento de águas servidas) para o surgimento de outros fluxos convergentes com o a incisão principal, aumentando a profundidade do canal. 0 material coluvial, transportado em momentos de tempestades ou mesmo pelo fluxo contínuo nas estações chuvosas, progressivamente construiu sobre o sopé da encosta um cone de dejeção. Sobre a incisão conectada à rede de drenagem, movimentos lentos de massa, provocados pela ação do rastejamento, forneceram quantidades suficientes de sedimentos para a formação de pequenas rupturas de declividade dentro da incisão. Em consequência, houve um aumento na atuação dinâmica da erosão linear em nível local. Acredita-se que este patamar crítico de estabilidade tenha sido atingido entre meados da década de 80 e 90. A atuação de um complexo sistema envolvido na modificação da 
geometria do relevo no terceiro momento (Figura 10 n.III) gerou o aprofundamento na incisão do canal desconectado e o solapamento de base da encosta. Na medida em que progressivamente a incisão desconectada fornecia sedimentos para formação do cone de dejeção, o material depositado, pouco coeso, sobre a atuação de fluxos superficiais e subsuperficiais promoveu uma interação sinergética, intensificando o processo de erosão linear.

Segundo Oliveira (1999), processos de liquefação por afloramento do lençol freático, associados ao escoamento superficial sobre as bordas de degraus construídos, podem provocar a formação de alcovas de regressão sobre o compartimento de meia encosta (Transportational midslope). Por outro lado, a atuação de fluxos supercríticos sobre as bordas da incisão tende a provocar a dissecação dos sulcos ou ravinas, alargando a incisão, favorecendo a evolução para uma voçoroca.

Outro mecanismo que pode ter atuado sobre a incisão foi resultante da queda d'água. Lâminas de água de descargas menores, que escorrem ao longo da parede de incisão, tendem a dissipar-se a jusante, dando origem ao que Oliveira (op.cit.) denominou por filetes subverticais de escoamento difuso. A infiltração de tais filetes sobre o sopé da encosta foi responsável pela esculturação de alcovas de regressão, ao passo que, sob a atuação de uma série de eventos chuvosos, as mesmas promoveram desmoronamentos periódicos, contribuindo para a extensão da incisão a montante. 

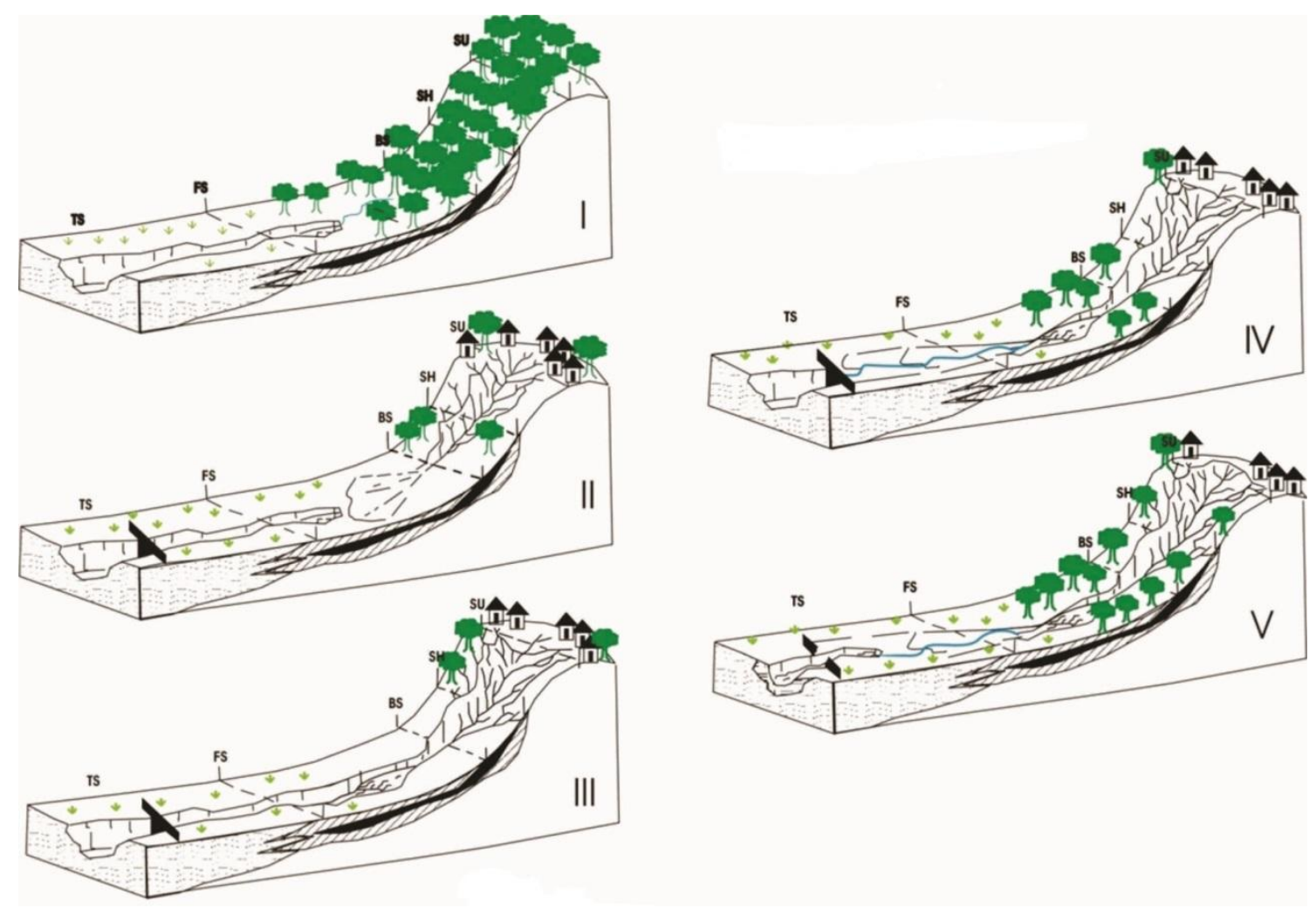

Figura 10. Modelo evolutivo sobre a voçoroca da BR-423 na área urbana de Garanhuns, representando a ocorrência de 5 momentos de evolução. A divisão da encosta é realizada pela compartimentação geométrica, como proposto por Ruhe (1974), sendo TS - toeslope; FS footslope; BS - backslope; SH - shouder; SU - summit. Fonte: Adaptado de Oliveira e Meis (1985).

A ocorrência de união entre os dois canais com o avanço da erosão linear a montante tendeu a construir vários degraus de ruptura, mantendo a erosão regressiva ativa. No entanto, a construção da barragem sobre a planície aluvial passou a exercer controle sobre o balanço de sedimentação em nível local. Grande quantidade de sedimentos foi continuamente retida iniciando um processo de colmatação do canal.

O fluxo perene de águas servidas conferiu para área, até o ano de 2007, uma maior taxa de saturação dos solos a jusante da cabeceira de drenagem. Processos de fluidização ocorreram sobre a base da voçoroca, fornecendo grande quantidade de fluxos de alta viscosidade para o eixo deposicional dos baixos pedimentos. Allen (1994) explica que o processo de fluidização ocorre através do empilhamento das partículas em estado de equilíbrio metaestável sobre a ação de um fluido. Este fluido permite que as partículas individuais experimentem um empuxo para cima, contrabalançado pelos seus pesos 
individuais. Dessa maneira, o fluido depositado rapidamente, em decorrência do desprendimento das partículas individuais, deu origem a um empacotamento frouxo dos sedimentos na porção do leque alúvio-coluvial que, pela atuação dos fluxos laminares perenes, sofreu uma retirada progressiva do material de fração $<62 \mu \mathrm{m}$, elevando a textura dos depósitos. Como resultado, a grande produção de sedimentos a jusante da voçoroca proporcionou a completa colmatação da barragem construída transversalmente sobre a incisão conectada à rede de drenagem.

Após a ocorrência do progressivo processo de reajustamento da geometria da encosta aos fatores de ordem externa, o período que se estendeu de janeiro a julho de 2004 foi decisivamente importante sobre a evolução da geomorfologia da área. A ocorrência de eventos chuvosos, sucessivos, de alta energia provocou a expansão a montante da incisão sobre a área de cabeceira e, ainda, o rompimento da barragem a jusante. $\mathrm{O}$ alargamento e aprofundamento da voçoroca foram sentidos pela população circunvizinha e pela própria população de Garanhuns, sobretudo pela destruição de metade da pista localizada na BR-423 (Figura 10 n.V).

Como resultado, no sopé da encosta, a barragem anteriormente colmatada após o seu rompimento transformou-se em um novo knickpoint. Consequentemente, houve a redinamização da área de deposição, provocando em microescala inversão do relevo e ainda a geração de um novo leque a jusante. Embora não tenha sido realizada uma análise por amostragem deste novo leque, percebeu-se uma mudança de textura após a posição terminal da barragem. Esta seletividade ocorreu provavelmente pela circulação das águas servidas atuando na remoção em quase sua totalidade do material terrígeno $<62 \mu \mathrm{m}$, como foi observado na análise granulométrica de LQG (leque aluvial da voçoroca). Assim, o caráter de drenagem "intermitente" do Riacho São Vicente permitiu a deposição dos sedimentos de textura mais fina imediatamente após a barragem.

Mesmo com a intervenção governamental que houve em 2007, após o agravamento do recuo desta escarpa, a área em questão (Figura 10 n. IV), antes considerada como uma cabeceira de drenagem de 
primeira ordem efêmera, passou a funcionar como um dos principais contribuintes da microbacia do Riacho São Vicente.

\section{A continuidade da problemática Erosiva em Garanhuns}

Problemas relacionados ao uso e ocupação de áreas vulneráveis em Garanhuns ainda continuam a acontecer no momento atual, sobretudo pela ausência de uma política de planejamento territorial efetiva no passado recente.

Algumas medidas tomadas entre os anos de 2009 e 2014, em curto prazo solucionaram problemas eminentes que, no entanto, não levaram em consideração o funcionamento geossistêmico entre as áreas ocupadas de topo e as áreas parcialmente protegidas em alta e média encosta, ou uso agrícola na baixa encosta e plaino aluvial.

Quantias exorbitantes foram gastas na construção de redes dispersoras de águas pluviais e recuperação de voçorocas que atingem bairros populares ou zonas periféricas do planalto de Garanhuns. Entretanto, muitas ações comandadas por construtoras e iniciativa privada continuam desrespeitando os códigos de proteção de áreas susceptíveis, como o caso da retirada de material de antigos campos de futebol para construção civil (fig. 11). Verificou-se que, em curto prazo, a especulação imobiliária em Garanhuns tem experimentado a construção de novos patamares sobre limites de ruptura de declividades, através do terraceamento com acréscimo de material retirado de áreas compostas principalmente por colúvio ou Latossolos Amarelos. 

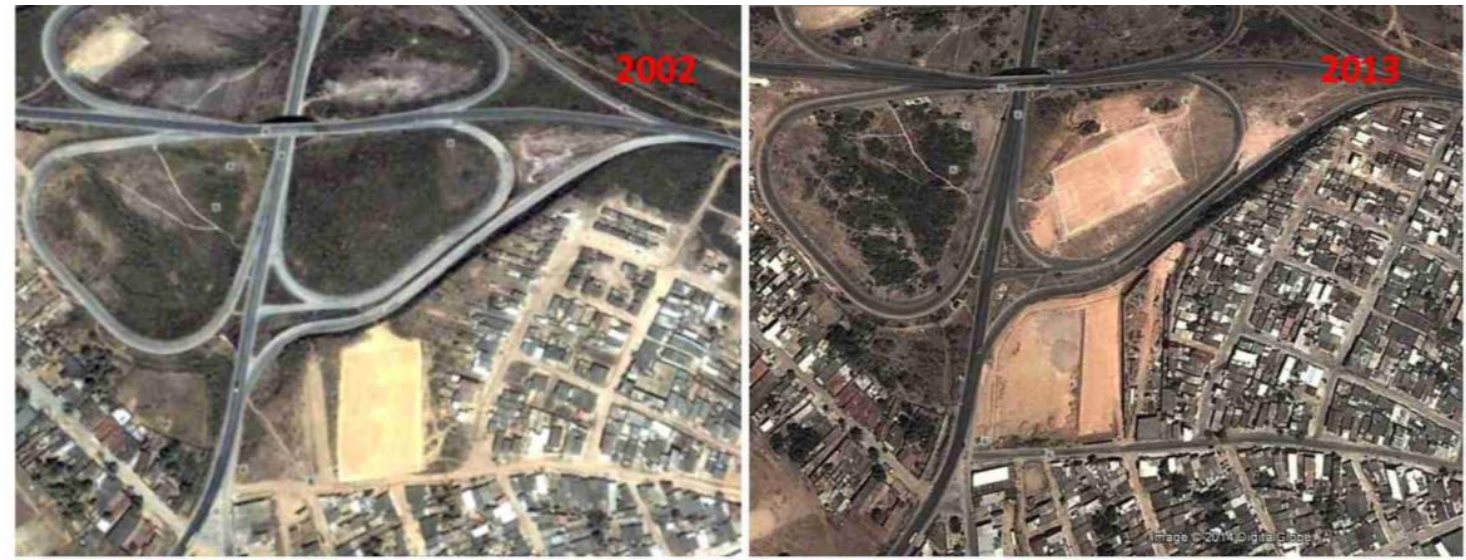

Figura 10. No ano de 2002, o terreno marcado em amarelo apresenta um antigo campo de futebol sobre uma área de

Latossolo Amarelo. A mudança de uso em 2013, demonstrada pela transferência do campo para uma área de domínio público, deveu-se ao uso e extração de material para constução civil desta área vinculado à especulação imobiliária de Garanhuns no período recente (Google Earth, 2015).

Muitas áreas anteriormente mapeadas como susceptíveis e inadequadas ao uso e ocupação têm sido sistematicamente loteadas e, consequentemente, expostas aos agentes erosivos. 0 elevado teor de areia e silte das coberturas superficiais em áreas de topo, de acordo com os resultados encontrados nesta pesquisa, tem conduzido aos terraços recém construídos a aceleração de processos erosivos sobre tais setores do relevo. Visto que a recuperação da voçoroca localizada na BR342 mobilizou uma grande quantidade de material de seu próprio leque aluvial para a reconstituição dos taludes, novos problemas surgiram a partir desta conduta. Na figura 12 é possível notar que a morfologia de encosta, não somente desta voçoroca, mas também de outras vertentes localizadas neste mesmo vale, modificou-se sensivelmente ao longo de quase 50 anos. 

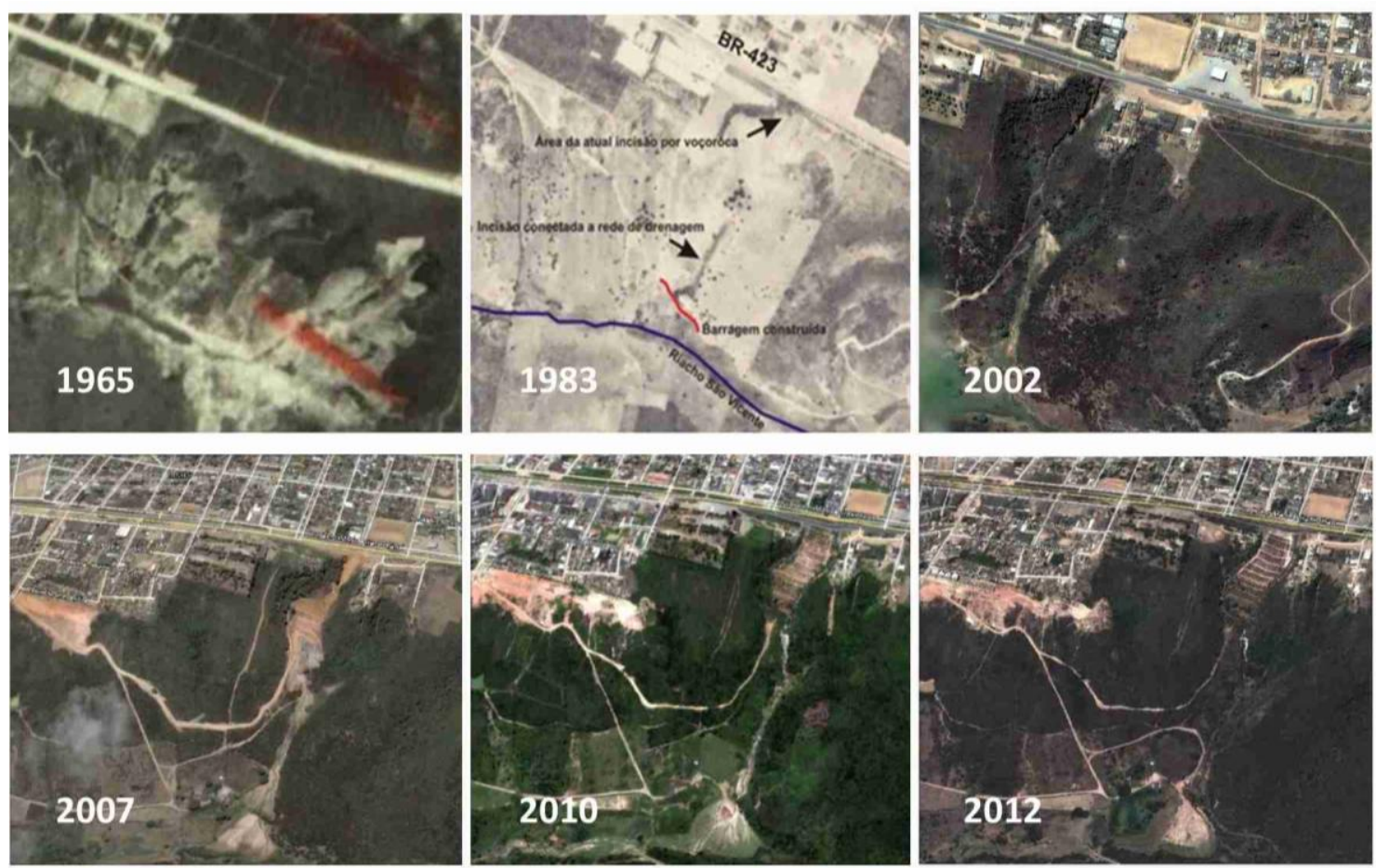

Figura 12. Evolução da paleovoçoroca e expansão urbana das áreas limítrofes do Planalto entre os anos de 1965 e 2012 . A partir de 2007 as obras de recuperação da voçoroca elevaram o fluxo de sedimentos para os leques e estes, por sua vez, foram utilizados na construção de novos patamares notados nos anos de 2010 e 2012 (Fontes: CPRM, 1965; INCRA,1982 e Google Earth, 2015).

Após a realização das obras de recuperação de uma das faixas da BR423 e retaludamento da voçoroca, maciças quantidades de sedimentos foram depositadas na posição terminal do leque aluvial, como observado na figura 12 (nos anos de 2007, 2010 e 2012). Com a instalação de vias para o trânsito de maquinário no fundo do vale, tais sedimentos passaram a ser utilizados tanto na própria voçoroca, bem como transferidos para a construção de terraços próximos à área afetada, objetivando o aumento da área de expansão de empreendimentos imobiliários. Não obstante, estes empreendimentos têm colaborado ainda com a falta de infraestrutura relativa à microdrenagem e baixa resistência do material estruturador, apresentando intenso ravinamento e possíveis reativações morfodinâmicas nestas áreas.

\section{CONCLUSÕES}


O desafio da realização de um desenvolvimento sustentável sobre a modelagem econômica regional cada vez mais tem se apoiado na aquisição de conhecimentos precisos dos sistemas geográficos. A compreensão e modelagem dos mecanismos interativos dos sistemas ambientais tem como objetivos principais dar suporte e potencializar as atividades socioeconômicas. Através do estudo realizado, pode-se constatar que as tendências de mudanças ambientais progressivamente têm refletido o cenário de expansão territorial, exploração dos recursos naturais e, principalmente, o uso inadequado do solo.

Muito tem se discutido acerca do crescimento das cidades e manutenção do Meio Ambiente em busca de uma melhor qualidade de vida, sobretudo no que concerne a expansão do uso e ocupação do solo. Apesar do Estatuto das Cidades estabelecer como dever das políticas urbanas estabelecer "normas de ordem pública e interesse social que regulam o uso da propriedade urbana em prol do bem-estar coletivo, da segurança e do bem estar dos cidadãos, bem como do equilíbrio ambiental" (Brasil, 2001) muitos problemas decorrentes de ações regulamentadas propriamente pelas administrações públicas não têm contribuído para a garantia de bem estar social como um todo.

Assim, o estudo de evolução morfodinâmica da área em apreço, bem como a análise dos fatores intervenientes sobre os processos superficiais da paisagem, demonstrou extrema fragilidade do sistema geomorfológico de Garanhuns quando em face às rápidas modificações climáticas e aquelas associadas à ação antrópica. Através do mapeamento morfodinâmico ficou constatado que a adoção de técnicas inadequadas de construção, infraestrutura deficiente e retirada da cobertura vegetal em áreas de cabeceira tem condicionado o aumento de processos erosivos em nível local. Sendo assim, o reconhecimento dos elementos físicos que caracterizam o terreno e os processos geomorfológicos dominantes comprova que estudos morfodinâmicos possuem importante papel na avaliação de áreas afetadas pelo planejamento urbano. Na verdade, estes estudos podem funcionar como mensuradores da qualidade do impacto das práticas de ordenação espacial. 
Cabe ao poder público coordenar e controlar, através de planejamento intersetorial, o crescimento urbano e a introdução de novos "estilos de vida", sobretudo quando antigas áreas rurais se convertem aceleradamente em "novo" solo urbano.

\section{REFERÊNCIAS}

ALLEN, J.R.L. Fundamental properties of fluids and their relation to sediment transport processes. In: PYE, K (ed). Sediment Transport and Depositional Process. Blackwell Scientific Publications: 1994, p.25-60.

AZAMBUJA, R. N. Análise Geomorfológica em áreas de expansão urbana no município de Garanhuns-PE. Recife, 2007, 148p. Dissertação (Mestrado em Geografia). DCG - Universidade Federal de Pernambuco.

BRASIL, Lei Federal 10.257 de 10.07.2001 - Estatuto da Cidade, 2001.

CAMARGO FILHO. M e BIGARELLA, J.J. Correlação de parâmetros estatísticos de sedimentos de vertente, rampas de coluvio-alúvio e terraços de várzea da bacia das Bananas - Guarapuava - PR. Geosul, v. 14, p. 438-442, 1998.

CASSETI, C. Geomorfologia. 2006. (Acesso em 20 de janeiro de 2015: www.funape.org.br/geomorfologia ).

CHORLEY, R.J. Geomorphology and general systems theory. U. S. Geological Survey, Professional Paper 500-B, 1962 (Tradução em Notícias Geomorfológica, 11 (21): 3-22, 1971).

CHRISTOFOLETTI, A. Modelagem de Sistemas Ambientais. São Paulo: Edgard Blücher, 1999. 236 p.

CORREA, A.C.B. Mapeamento Geomorfológico de Detalhe do maciço da Baixa Verde - Estudo da relação entre a distribuição dos sistemas Geoambientais e Compartimentação Geomorfológica. Recife, 1997, 182p. Dissertação de Mestrado - DCG - Universidade Federal de Pernambuco.

CORREA, A.C.B. Dinâmica geomorfológica dos compartimentos elevados do Planalto da Borborema, Nordeste do Brasil. Rio Claro, 2001. 386p. Tese de Doutorado - IGCE, UNESP.

COSTA FILHO, A. Estudo Geológico da Folha Garanhuns-PE- Área D. Recife, 1978. 112 p. Relatório de Graduação. Departamento de Geologia - Universidade Federal de Pernambuco.

CPRM - COMPANHIA DE RECURSOS MINERAIS. Governo do Estado de Pernambuco. Geologia e Recursos Minerais do Estado de Pernambuco. Recife: CPRM, 2001.

CZAJKA, W. Estudos Geomorfológicos do Nordeste Brasileiro. In: Revista Brasileira de Geografia. Rio de Janeiro: 20(2): p.135-180,1959.

KERTZMAN, F. F; OLIVEIRA, A. M.S; SALOMÃO, F.X.T \& GOUVEIA, M.I.F. Mapa de Erosão do Estado de São Paulo. In: Revista do Instituto Geológico. São Paulo, Volume especial: p31-36, 1995.

KING. L. A Geomorfologia do Brasil Oriental. Separata da Rev. Brasileira de Geografia, 2: 1957. 121p.

MABESSONE, J.M. \& CASTRO, C. Desenvolvimento do Geomorfológico do Nordeste Brasileiro. In: Boletim da Sociedade de Geologia Núcleo Nordestino, Recife (3): 5-36, 1975. 
MODENESI, M.C. Depósitos de Vertente e Evolução Quaternária no Planalto do Itatiaia. Rev. do Instituto Geológico. 13 (1): $31-46,1992$.

MODENESI, M.C. \& TOLEDO, M.C.M. de. Morfogênese Quaternária e intemperismo: Colúvios do Planalto do Itatiaia. In: Rev. do Instituto Geológico. São Paulo: n. 14(1), p.43-53, 1993.

MODENESI-GAUTTIERI, M. C. \& HIRUMA, S.T. A expansão Urbana no Planalto de Campo dos Jordão. Diagnóstico Geomorfológico para fins de Planejamento. In: Rev. do Instituto Geológico, São Paulo, 25 (1/2), 1-28, 2004.

NIMER, E. Climatologia do Brasil. 2a ed. Rio de Janeiro: IBGE, 1989, pp.315-361.

OLIVEIRA, M.A.T. \& MEIS. Relações entre geometria do relevo e formas de erosão linear acelerada (Bananal, SP). Rev. de Geociências. 4:87-99, 1985.

OLIVEIRA, M.A.T. Processos erosivos e preservação de áreas de risco de erosão por voçorocas. In: GUERRA, A.J.T.; SILVA, A.S. e BOTELHO, R.G.M. (eds.) Erosão e Conservação dos Solos: Conceitos, temas e Aplicações. Bertrand Brasil: Rio de Janeiro, 1999, p. 57-99.

PEDRO, F. G. \& LORANDINI, R. Potencial Natural de Erosão na Área Periurbana de São Carlos -SP. In: Revista Brasileira de Cartografia. 56/01: p 28-33, 2004.

RIBEIRO, S.C. Susceptibilidade aos processos erosivos superficiais com base na dinâmica geomorfológica na Microbacia do Rio Granjeiro, Crato-CE. Rio de Janeiro, 2004, 120p. Dissertação de Mestrado - Universidade Federal do Rio de Janeiro.

ROSS, J.L.S. Geomorfologia: Ambiente e Planejamento. São Paulo: 8ª ed. Contexto, 2005. 84p

SANTORO, J. \& FULFARO, V.J. Estudo Geotécnico em Boçorocas na Cidade de São Pedro, São Paulo (SP). In: Revista do Instituto Geológico. São Paulo, 17 (1/2), 55-62, jan./dez, 1996.

SILVA, D.G.; CORRÊIA, A.C.B.; SOUZA, A.O.; MELO, J.S.; LAMAS, R.C. \& NÓBREGA, P.R.C. Contribution to the interpretation the erosive behavior on the hills of Guabiraba, Recife-PE, Northeastern Brazil: Sedimentological analysis of the superficial structure of landscape. In: Rev. Sociedade Natureza, special Issue, 488-493, May, 2005.

TRICART, J. Ecodinâmica, Rio de Janeiro: FIBGE/SUPREN, 1977. 